\title{
Effect of dietary intake of phenolic compounds from mango peel extract on growth, lipid peroxidation and antioxidant enzyme activities in zebrafish (Danio rerio)
}

\author{
Cynthia E. Lizárraga-Velázquez ${ }^{1}$, Crisantema Hernández ${ }^{1}$ \\ Gustavo A. González-Aguilar ${ }^{2}$ \& José B. Heredia ${ }^{3}$ \\ ${ }^{1}$ Food Research and Development Center A.C., Mazatlán, Sinaloa, México \\ ${ }^{2}$ Food Research and Development Center A.C., Hermosillo, Sonora, México \\ ${ }^{3}$ Food Research and Development Center A.C., Culiacán, Sinaloa, México \\ Corresponding author: Crisantema Hernández (chernandez@ciad.mx)
}

\begin{abstract}
Four experimental diets were formulated with 50, 100, 150 and $200 \mathrm{mg}$ of phenolic compounds (PCs) $\mathrm{kg}^{-1}$ feed, derived from mango peel. The control diet did not contain PCs. A total of 120 male zebrafish (Danio rerio) (average weight: $166 \mathrm{mg}$ ) were fed for eight weeks to assess the ability of PCs to prevent lipid peroxidation and enhance antioxidant status. Growth performance was calculated at the end of the experimental trial. Lipid peroxidations in muscle and antioxidant enzyme activity in the liver were evaluated at the end of the experiment. There was no significant difference in growth performance among treatments. Malondialdehyde (MDA) levels in muscle were significantly lower in fish fed diets containing 50 and $100 \mathrm{mg}$ of PCs per $\mathrm{kg}$ of feed. Incorporation of PCs into zebrafish diet did not have any significant effects on glutathione peroxidase and superoxide dismutase activity. However, catalase (CAT) activity increased significantly in fish with diets containing 100, 150 and $200 \mathrm{mg}$ of PCs kg-1 feed. These results suggest a potential protective effect against in vivo lipid peroxidation and CAT-modulating effects.
\end{abstract}

Keywords: Danio rerio; mango peel; phenolic compounds; antioxidant enzymes; lipid peroxidation; oxidative stress

\section{INTRODUCTION}

In general, fish contain high levels of long-chain omega-3 ( $\omega 3)$ polyunsaturated fatty acids ( $\omega 3$ PUFAs) such as all-cis-4,7,10,13,16,19-docosahexaenoic acid (DHA; 22:6, $\omega 3$ ) and all cis-5,8,11,14,17-eicosapentaenoic acid (EPA; 20:5, 03 ), which constitute the phospholipids of cell membranes, providing structural and functional maintenance (Ardiansyah \& Indrayani, 2007; Ayala et al., 2014). Paradoxically, 03 PUFAs are highly susceptible to lipid peroxidation by reactive oxygen species (ROS) such as the superoxide anion $\left(\mathrm{O}_{2}{ }^{-}\right)$, hydroxyl radical $\left(\mathrm{OH}^{*}\right)$ and hydroperoxyl radical $\left(\mathrm{HO}_{2}{ }^{\circ}\right)$. These molecules are produced during normal cellular metabolism, malnutrition, biotic and abiotic factors and/or fish handling, and may increase ROS production and induce oxidative stress (MartínezÁlvarez et al., 2005). Lipid peroxidation products, such as lipid peroxyl radicals and malondialdehyde (MDA, a good indicator of oxidative damage to lipids), can affect the nutritional quality (e.g., decrease $\omega 3$ PUFAs content) of fish intended for human consumption (Secci \& Parisi, 2016). Also, there is an increased interest to prevent peroxidation of $\omega 3$ PUFAs in fish since they have been related to the prevention of cardiovascular and inflammatory diseases in humans (Delgado-Lista et al., 2012).

Assessment of oxidative stress indicators in farmed fish can be used as an index of welfare and muscle quality of fish of commercial interest (Sicuro et al., 2010; Chulayo \& Muchenje, 2015; Villasante et al., 2015). Analyses of oxidative stress indicators in different tissues can be performed to provide additional information about fish health (Poli, 2009). For example, the fish liver has an important role in detoxification, and its enzymatic antioxidant defense

Corresponding editor: Jesús Ponce Palafox 
system helps to maintain redox homeostasis (Li et al., 2015; Martínez-Álvarez et al., 2005). The main enzymes responsible for the antioxidant response measured in fish are catalase (CAT), superoxide dismutase (SOD) and glutathione peroxidase (GPX), which act jointly to protect cells against oxidative damage (Martínez Álvarez et al., 2005; Karadag et al., 2014).

In the absence of adequate antioxidant enzyme activities, MDA concentration increases in fish muscle, which diminishes its quality. Plant extracts that are natural antioxidants have been used as dietary additives to protect tissues of fish, of commercial interest; rainbow trout (Oncorhynchus mykiss), Atlantic salmon (Salmo salar) and gilthead sea bream (Sparus aurata), against oxidative damage to lipids and enhance fish welfare (Lizárraga-Velázquez et al., 2018a).

Mango (Mangifera indica) contains phenolic compounds (PCs) with high antioxidant activity (Velderrain-Rodríguez et al., 2015). Mango cv. "Ataulfo" is a Mexican variety of high agronomic importance; it is used to produce juices, concentrates and snacks, but generates by-products currently considered industrial waste. Mango byproducts, such as peels, have a high PCs content which is capable of preventing lipid peroxidation of fish oil (LizárragaVelázquez et al., 2018b). There are multiple in vitro and in vivo studies reporting the anti-inflammatory, anticancer, anti-diabetic and anti-obesogenic potential of mango peel PCs (Shah et al., 2010); however, their antioxidant benefits have not been explored in fish. Therefore, this study aimed to evaluate the ability of mango peel PCs to delay lipid peroxidation in muscle and enhance antioxidant status in the liver of zebrafish (Danio rerio), which is considered a good aquaculture model.

\section{MATERIALS AND METHODS}

\section{Processing of mango peels}

Mango peels (Mangifera indica cv. Ataulfo) were collected from Pure Mango S.A. of C.V., Escuinapa, Sinaloa, México. Fresh mango peels $(50 \mathrm{~kg})$ were dried at $50^{\circ} \mathrm{C}$ for $15 \mathrm{~h}$ in convective hot air and ground to a particle size of $0.25 \mathrm{~mm}$ using a hammer mill (California Pellet Mill Laboratory Mill Champion, Waterloo, IA, USA). Mango peel powder was stored at $-20^{\circ} \mathrm{C}$ until analysis.

\section{Extraction of phenolic compounds}

Mango peel PCs were extracted according to SekhonLoodu et al. (2013) with minor modifications. Mango peel powder $(10 \mathrm{~g})$ was homogenized in $1 \mathrm{~L}$ of $70 \%$ ethanol, sonicated three times for $15 \mathrm{~min}$ in a 3510 model ultrasonic bath (Branson, Wethersfield, CT, USA). After sonication, samples were centrifuged $\left(3,000 \mathrm{~g}, 15 \mathrm{~min}, 4^{\circ} \mathrm{C}\right)$ in an Allegra X-30R model A99470 centrifuge (Beckman Coulter, Germany). Finally, a Rotavapor R-114 (Büchi Labortechnik AG, Flawil, Switzerland) was used $\left(37^{\circ} \mathrm{C}\right)$ to remove the ethanol and concentrate the supernatants. Total phenolic content (TPC) was determined with the FolinCiocalteu reagent using gallic acid as standard. After knowing TPC, dilutions were prepared with concentrations of 50, 100, 150 and $200 \mathrm{mg}$ of PCs.

\section{Analysis of PCs by UPLC ESI-Q-TOF/MS/MS}

PCs from mango peel were identified using UltraPerformance Liquid Chromatography (UPLC) using ACQUITY UPLC; H-Class system (Waters, Milford, MA, USA) coupled to a G2 XS Quadrupole-Time-ofFlight (Q-Tof) mass spectrometer (Agilent, Santa Clara, CA, USA) equipped with electrospray ionization (ESI). Briefly, PCs were separated by UPLC at $40^{\circ} \mathrm{C}$ with a column ACQUITY BEH C18 $(1.7 \mu \mathrm{m}, 3.0 \times 100$ $\mathrm{mm}$ ) using a mobile phase composed of $0.1 \%$ formic acid (A) and acetonitrile (B) at a flow rate of $0.3 \mathrm{~mL}$ $\mathrm{min}^{-1}$. The gradient procedure was as follows: $0 \mathrm{~min}$, 95\% (A); $2.5 \mathrm{~min}, 75 \%$ (A); $3 \mathrm{~min}, 50 \%$ (A); $3.5 \mathrm{~min}$, 35\% (A); $5 \mathrm{~min}, 5 \%$ (A); $6 \mathrm{~min}, 95 \%$ (A); and $7 \mathrm{~min}$, 95\% (A). An electrospray source in negative mode was used to collect mass spectra under the following conditions: nitrogen gas; desolvation temperature, $350^{\circ} \mathrm{C}$; desolvation gas, $13.3 \mathrm{~L} \mathrm{~min}^{-1}$; capillary voltage, $1500 \mathrm{~V}$; and fragmentor voltage, $10 \mathrm{~V}$.

\section{Experimental diets}

The preparation of the experimental diets was carried out as follows: fish meal, fish oil, dextrin, cellulose, soy lecithin, alginate, mineral premix, vitamin premix, vitamin $\mathrm{C}$ and synthetic antioxidant butylated hydroxytoluene (BHT), were used to prepare the control diet. Four additional diets were prepared and supplemented with PCs from the mango peel extract (MPE) at concentrations of 50,100, 150 and $200 \mathrm{mg}$ PCs kg ${ }^{-1}$ feed. These were denoted as MPE-5, MPE-10, MPE-15 and MPE-20, respectively (Table 1). Fish meal was ground in a hammer mill to a particle size of 250 $\mu \mathrm{m}$. The macronutrients (fish meal, dextrin, cellulose and alginate) were mixed in a model AT-200 Hobart mixer (Offenburg, Germany), and the micronutrients (mineral premix, vitamin premix, vitamin $\mathrm{C}$ and $\mathrm{BHT}$ ) were added. Fish oil and soy lecithin were added. Finally, PCs that had been homogenized in warm water were added until a homogeneous mixture was obtained. The resulting mash was passed through a model 22 meat grinder $\left(\right.$ Torrey ${ }^{\circledR}, \mathrm{IN}$, USA) to produce pellets, 
Table 1. Ingredients, proximate composition and PCs content of the experimental diets administered to zebrafish Danio

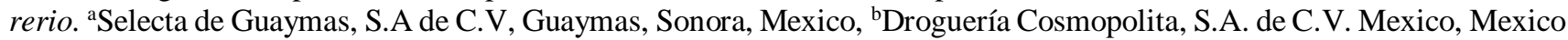

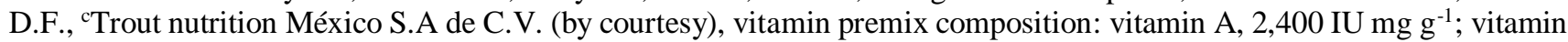
D3, 2,250 IU; vitamin E, $160 \mathrm{~g}$; vitamin K3 $8.00 \mathrm{~g}$; vitamin B1, $20.00 \mathrm{~g}$; vitamin B2, $40.00 \mathrm{~g}$; vitamin B6, $16.00 \mathrm{~g}$; pantothenic acid, $60.00 \mathrm{~g}$; folic acid, $4.00 \mathrm{~g}$; vitamin B12, $80 \mathrm{mg}$; nicotinic acid, $160.00 \mathrm{~g}$; biotin, $500 \mathrm{mg}$; vitamin C, 100

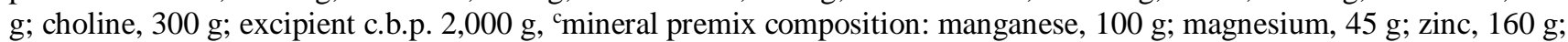
iron, $200 \mathrm{~g}$; copper, $20 \mathrm{~g}$; iodine, $5 \mathrm{~g}$; selenium $400 \mathrm{mg}$; cobalt $600 \mathrm{mg}$, ${ }^{\mathrm{d} D S M}$ Nutritional Products Mexico S.A. de C.V., El Salto, Jalisco, Mexico, ${ }^{\mathrm{e} S i g m a-A l d r i c h ~ C h e m i c a l, ~ S . A . ~ d e ~ C . V . ~ T o l u c a, ~ M e x i c o, ~}{ }^{\mathrm{f}}$ phenolic compounds from MPE, ${ }^{\mathrm{g}}$ Mean $\pm \mathrm{SD}$, number of replicates $=3,{ }^{\mathrm{h}}$ Nitrogen-free extract (including fiber $)=100-(\%$ protein $+\%$ lipid $+\%$ ash $),{ }^{\mathrm{i}}$ gross energy $\left(\mathrm{kJ} \mathrm{g}^{-1}\right)$ was calculated according to the physiological fuel values of protein, $20.93 \mathrm{~kJ} \mathrm{~g}^{-1}$; lipids, $37.68 \mathrm{~kJ} \mathrm{~g}^{-1}$; and nitrogenfree extract, $16.75 \mathrm{~kJ} \mathrm{~g}^{-1}$.

\begin{tabular}{|c|c|c|c|c|c|}
\hline \multirow{2}{*}{ Ingredients (\%) } & \multicolumn{5}{|c|}{ Diet } \\
\hline & Control & MPE-5 & MPE-10 & MPE-15 & MPE-20 \\
\hline Fish meal $^{\mathrm{a}}$ & 73 & 73 & 73 & 73 & 73 \\
\hline Fish oil ${ }^{\mathrm{b}}$ & 8 & 8 & 8 & 8 & 8 \\
\hline Dextrin $^{b}$ & 3 & 3 & 3 & 3 & 3 \\
\hline Celulose ${ }^{\mathrm{b}}$ & 10.560 & 10.547 & 10.542 & 10.537 & 10.532 \\
\hline Soy lecithin ${ }^{b}$ & 0.60 & 0.60 & 0.60 & 0.60 & 0.60 \\
\hline Minerals premix ${ }^{c}$ & 0.23 & 0.23 & 0.23 & 0.23 & 0.23 \\
\hline Vitamin premix ${ }^{c}$ & 0.10 & 0.10 & 0.10 & 0.10 & 0.10 \\
\hline Vitamin $C^{d}$ & 3 & 3 & 3 & 3 & 3 \\
\hline Alginate ${ }^{\mathrm{e}}$ & 1.50 & 1.50 & 1.50 & 1.50 & 1.50 \\
\hline BHT $^{\mathrm{e}}$ & 0.01 & 0.01 & 0.01 & 0.01 & 0.01 \\
\hline Total phenolic compounds ${ }^{\mathrm{f}}$ & 0 & 0.005 & 0.01 & 0.015 & 0.02 \\
\hline \multicolumn{6}{|c|}{ Proximate composition (\% dry matter $)^{\mathrm{g}}$} \\
\hline Crude protein & $54.62 \pm 0.21$ & $54.49 \pm 0.19$ & $54.59 \pm 0.11$ & $54.71 \pm 0.33$ & $54.56 \pm 0.17$ \\
\hline Crude lipid & $12.39 \pm 0.33$ & $12.04 \pm 0.30$ & $12.17 \pm 0.18$ & $12.39 \pm 0.54$ & $12.33 \pm 0.27$ \\
\hline Ash & $15.83 \pm 0.25$ & $15.89 \pm 0.04$ & $15.72 \pm 0.25$ & $15.73 \pm 0.09$ & $15.85 \pm 0.04$ \\
\hline $\mathrm{NFE}^{\mathrm{h}}$ & $17.16 \pm 0.32$ & $17.58 \pm 0.12$ & $17.52 \pm 0.34$ & $17.17 \pm 0.19$ & $17.26 \pm 0.14$ \\
\hline Gross energy $\left(\mathrm{kJ} \mathrm{g}^{-1}\right)^{\mathrm{i}}$ & 18.97 & 18.88 & 18.94 & 18.99 & 18.95 \\
\hline
\end{tabular}

which were dried at $38^{\circ} \mathrm{C}$ for $12 \mathrm{~h}$, reduced to a $600 \mu \mathrm{m}$ diameter and stored at $4^{\circ} \mathrm{C}$ until use.

\section{Chemical analysis}

Ingredients and diets were analyzed to determine moisture, crude protein, crude fat and ash content (method 942.05; AOAC, 2000). Moisture was determined using a Craft stove (method 930.15; AOAC, 2000). Crude protein was identified with the Dumas combustion method (Ebeling, 1968) using a Flash 2000 Organic Elemental Analyser (Thermo Scientific, Italy). Crude fat content was analyzed using a micro Soxhlet Foss Soxtec Avanti 2050 Automatic System (Foss Soxtec, Hoganäs, Sweden) using an official method (method 920.39; AOAC, 2000). Ash content was analyzed by calcination of the samples in a muffle furnace at $550^{\circ} \mathrm{C}$ (Fisher Scientific International, Pittsburgh, PA, USA) using an official method (method 942.05; AOAC, 2000).

The PCs content in the experimental diets was analyzed to determine the final concentration in zebrafish (Danio rerio) feed. Briefly, diets $(0.5 \mathrm{~g})$ were homogenized in $20 \mathrm{~mL}$ of $70 \%$ ethanol, stirred for $24 \mathrm{~h}$ at $20^{\circ} \mathrm{C}$, and sonicated for $15 \mathrm{~min}$. After sonication, samples were centrifuged $\left(3,000 \mathrm{~g}, 15 \mathrm{~min}, 4^{\circ} \mathrm{C}\right)$ and supernatants were collected. PCs content was determined with the Folin-Ciocalteu reagent using gallic acid as standard.

\section{Fish rearing and feeding}

Adult zebrafish were obtained from the Bioassay Laboratory in aquatic organisms of the Research Center for Food and Development (CIAD, Mazatlán Unit), which come from a standardized genetic line (line AB, www.zfin.org). A completely randomized experimental design with three replicates per treatment was used. A total of 120 male zebrafish with a mean initial weight of $166 \pm 1 \mathrm{mg}$ were maintained under a $12 \mathrm{~h}$ light-dark cycle. Zebrafish were placed in 15 aquarium tanks (6 L) in groups of eight fish; each tank had a static renewal system. The effect of PCs on growth performance and the antioxidant response was evaluated using the following feeding protocol: zebrafish were fed twice a day manually (9:00 and 
16:00 h) to apparent satiety for eight weeks. Each morning, fecal matter and excess leftover feed were carefully siphoned out from the bottom of each tank, and $30 \%$ water volume was renewed daily. Water conditions were temperature $27 \pm 0.5^{\circ} \mathrm{C}, \mathrm{pH} 6.9 \pm 0.5$, dissolved oxygen $5.0 \pm 0.3 \mathrm{mg} \mathrm{L}^{-1}$ and chlorine $0.0 \mathrm{mg}$ $\mathrm{L}^{-1}$.

\section{Growth parameters and feed efficiency}

Fish were weighed individually under anesthesia $[0.005 \%(w / v)$ tricaine (Sigma-Aldrich, St. Louis, MO, USA)] every two weeks to calculate their mean body weight. Growth and feed efficiency of the fish were monitored regarding weight gain (WG), specific growth rate (SGR), survival (S), feed intake (FI), feed conversion ratio (FCR), the protein efficiency ratio (PER) and hepatosomatic index (HSI). Biological indicators were calculated as follows: $\mathrm{WG}(\mathrm{mg})=[$ final mean weight - initial mean weight]; SGR $(\% /$ day $)=$ $[100 \times(\ln$ (final mean body weight) $-\ln$ (initial mean body weight)) / number of days]; $\mathrm{S}(\%)=($ final number/initial number $) \times 100$; FI $\left(\mathrm{mg}\right.$ fish $\left.^{-1}\right)=$ $\sum_{\mathrm{i}} 60$ [(total feed consumption) / (number of fish)] / number of days; FCR = feed intake/weight gain; PER = weight gain / protein intake and HSI $(\%)=$ (liver weight / body weight) $\times 100$.

\section{Muscle lipid peroxidation}

The head, tail and viscera were removed from each fish to quantify lipid peroxidation. Four fishes (about 400 $\mathrm{mg}$ ) from each tank were homogenized (Ultra-Turrax D25 basic, IKA ${ }^{\Theta}$-Werke, Germany) with $1.2 \mathrm{~mL}$ of PBS buffer ( $\mathrm{pH}$ 7.4). Homogenized samples were centrifuged at $3,000 \mathrm{~g}$ for $15 \mathrm{~min}$ at $4^{\circ} \mathrm{C}$; supernatants were recovered and used to quantify peroxidized lipids as described by Solé et al. (2004). Briefly, $200 \mu \mathrm{L}$ of the homogenate was mixed with $1,300 \mu \mathrm{L}$ of 1 -methyl2-phenylindole $(10.3 \mathrm{mM})$ in methanol: acetonitrile (1:3; v/v), $200 \mu \mathrm{L}$ of water and $300 \mu \mathrm{L}$ of $37 \% \mathrm{HCl}$. This mixture was incubated at $45^{\circ} \mathrm{C}$ for $40 \mathrm{~min}$, cooled on ice for $10 \mathrm{~min}$ and centrifuged at 3,000 $\mathrm{g}$ for $15 \mathrm{~min}$ at $4{ }^{\circ} \mathrm{C}$. Absorbance was read at $586 \mathrm{~nm}$, and the amount of peroxidized lipids (nmol MDA g ${ }^{-1}$ of tissue; w/w) was calculated using a standard solution of 1,1,3,3tetraethoxypropane $(10 \mathrm{mM})$.

\section{Hepatic antioxidant-enzyme activities}

On the last day of the experiment, zebrafish were euthanized under anesthesia with $0.0075 \%$ (w/v) tricaine (Sigma-Aldrich, MO, USA). The liver was removed and manually homogenized in $300 \mu \mathrm{L}$ of PBS buffer (pH 7.4) and centrifuged at 3,000 $\mathrm{g}$ for $15 \mathrm{~min}$ at $4^{\circ} \mathrm{C}$. The supernatant was used to determine total protein content and antioxidant enzyme activities. Total protein content was determined using Bradford's reagent (Bradford, 1976) and bovine serum albumin as a standard. The CAT activity was determined using a Cayman Chemical kit (Ann Arbor, MI, USA); one unit of CAT was defined as the amount of enzyme that catalyzed the formation of $1 \mathrm{nmol}$ of formaldehyde per minute at $25^{\circ} \mathrm{C}$. GPX activity was measured using a Cayman Chemical kit; one unit of GPX was defined as the amount of enzyme that catalyzed the oxidation of 1 nmol of NADPH to $\mathrm{NADP}^{+}$per minute at $25^{\circ} \mathrm{C}$. The SOD activity was assayed using a Sigma-Aldrich kit; one unit of SOD was defined as the amount of enzyme that inhibited the formation of WST-1 formazan by $50 \%$. All enzyme activity results were expressed as specific enzyme activity in $\mathrm{U} \mathrm{mg}^{-1}$ protein.

\section{Statistical analysis}

Data were evaluated for normality (KolmogorovSmirnov test) and homogeneity of variance (Levene's test) before statistical analyses. Dependent variables (growth performance, MDA content and antioxidant enzymes activities) were analyzed using a one-way analysis of variance (ANOVA); a post-hoc Tukey's test was conducted when significant differences were found $(P<0.05)$. Before statistical analysis, the percentages (SGR, S and HSI) were transformed to arcsine, but results were reported as a percentage. Statistical analyses were run using Statistica v.7 (StatSoft, Inc., 2004).

\section{RESULTS}

\section{Mango peel extract (MPE) phenolic compounds (PCs) profile}

Eight PCs were identified, five of which were phenolic acids, two flavonoids and a polyphenol, xanthone (Table 2). Gallic acid (m/z [M-H]', 169.01), 2-hydroxicinnamic acid $\left(\mathrm{m} / \mathrm{z}[\mathrm{M}-\mathrm{H}]^{-}, 163.038\right)$, mangiferin $(\mathrm{m} / \mathrm{z}$ $\left.[\mathrm{M}-\mathrm{H}]^{-}, 421.089\right)$ and quercetin $\left(\mathrm{m} / \mathrm{z}[\mathrm{M}-\mathrm{H}]^{-}, 301.035\right)$ were identified by comparing the $\mathrm{m} / \mathrm{z}[\mathrm{M}-\mathrm{H}]^{-}$and fragment ions with standards. Methyl gallate $(\mathrm{m} / \mathrm{z}$ [M$\left.\mathrm{H}^{-}, 183.027\right)$, ethyl gallate $\left(\mathrm{m} / \mathrm{z}[\mathrm{M}-\mathrm{H}]^{-}, 197.041\right)$ and isoquercitrin $\left(\mathrm{m} / \mathrm{z}[\mathrm{M}-\mathrm{H}]^{-}, 463.085\right)$ were compared with literature. Protocatechuic acid $(\mathrm{m} / \mathrm{z}[\mathrm{M}-\mathrm{H}]$, 153.014) was confirmed with MassBank of North America (http://mona.fiehnlab. ucdavis.edu).

\section{Growth and feed efficiency parameters}

The WG, SGR, S, FI, FCR, PER and HSI were not significantly affected by supplementation of PCs from MPE into the diet of zebrafish (Danio rerio) (Table 3). Zebrafish survival was greater than $90 \%$, and no significant difference $(P>0.05)$ among the different dietary treatments was observed. 
Table 2. PCs detected in mango peel cv. Ataulfo extract by UPLC-ESI Q-Tof-MS/MS. aConfirmed with the standard, ${ }^{\mathrm{b}}$ confirmed with literature (Dorta et al., 2014), ${ }^{\mathrm{c}}$ confirmed with database (MassBank of North America).

\begin{tabular}{|c|c|c|c|c|}
\hline Identification & $\begin{array}{c}\text { Retention } \\
\text { time (min) }\end{array}$ & $\mathrm{m} / \mathrm{z}[\mathrm{M}-\mathrm{H}]^{-}$ & $\begin{array}{l}\text { Fragment ions MS'MS } \\
(\mathrm{m} / \mathrm{z})[\mathrm{M}-\mathrm{H}]^{-}\end{array}$ & $\begin{array}{l}\text { Molecular } \\
\text { formula }\end{array}$ \\
\hline Gallic acid $^{\mathrm{a}}$ & 1.521 & 169.010 & 125.017 & $\mathrm{C}_{7} \mathrm{H}_{6} \mathrm{O}_{5}$ \\
\hline 2-Hydroxycinnamic acid & 4.180 & 163.038 & $119.044,136.922,138.925$ & $\mathrm{C}_{7} \mathrm{H}_{6} \mathrm{O}_{5}$ \\
\hline Mangiferin ${ }^{a}$ & 3.482 & 421.089 & $301.035,331.045$ & $\mathrm{C}_{19} \mathrm{H}_{18} \mathrm{O}_{11}$ \\
\hline Quercetin $^{\mathrm{a}}$ & 4.817 & 301.035 & $179.997,150.999,152.002$ & $\mathrm{C}_{15} \mathrm{H}_{10} \mathrm{O}_{7}$ \\
\hline Methyl gallate ${ }^{b}$ & 3.425 & 183.027 & 124.010 & $\mathrm{C}_{8} \mathrm{H}_{8} \mathrm{O}_{5}$ \\
\hline Ethyl gallate $^{\mathrm{b}}$ & 4.328 & 197.041 & $124,125,169.010$ & $\mathrm{C}_{9} \mathrm{H}_{10} \mathrm{O}_{5}$ \\
\hline Isoquercitrin ${ }^{b}$ & 4.283 & 463.085 & $301.035,300.030$ & $\mathrm{C}_{21} \mathrm{H}_{20} \mathrm{O}_{12}$ \\
\hline Protocatechuic acid ${ }^{c}$ & 2.585 & 153.014 & $108.020,109.020$ & $\mathrm{C}_{7} \mathrm{H}_{6} \mathrm{O}_{4}$ \\
\hline
\end{tabular}

Table 3. Growth parameters and feed efficiency of zebrafish (Danio rerio) fed experimental diets for eight weeks. ${ }^{a}$ Data is expressed as mean \pm SD for three tanks per group, eight fish each. IW: initial weight, FW: final weight, WG: weight gain, SGR: specific growth rate, S: survival, FI: feed intake, FCR: factor conversion ratio, PER: protein efficiency ratio, HSI: hepatosomatic index.

\begin{tabular}{lrcrrr}
\hline \multirow{2}{*}{ Parameter } & \multicolumn{5}{c}{ Diet } \\
\cline { 2 - 6 } & \multicolumn{1}{c}{ Control } & \multicolumn{1}{c}{ MPE-5 } & \multicolumn{1}{c}{ MPE-10 } & \multicolumn{1}{c}{ MPE-15 } & \multicolumn{1}{c}{ MPE-20 } \\
\hline IW $(\mathrm{mg})$ & $162.00 \pm 0.07$ & $162.00 \pm 0.06$ & $162.00 \pm 0.06$ & $162.00 \pm 0.06$ & $162.00 \pm 0.06$ \\
FW $(\mathrm{mg})$ & $194.82 \pm 0.99$ & $193.39 \pm 2.53$ & $193.87 \pm 1.08$ & $192.56 \pm 1.16$ & $193.51 \pm 0.99$ \\
WG $(\mathrm{mg})$ & $32.32 \pm 0.99$ & $30.89 \pm 2.53$ & $31.37 \pm 1.08$ & $30.06 \pm 1.16$ & $31.01 \pm 0.92$ \\
SGR $\left(\% \mathrm{~d}^{-1}\right)$ & $0.30 \pm 0.01$ & $0.29 \pm 0.03$ & $0.29 \pm 0.01$ & $0.28 \pm 0.01$ & $0.29 \pm 0.01$ \\
S $(\%)$ & $91.60 \pm 7.21$ & $91.60 \pm 14.43$ & $91.60 \pm 7.21$ & $95.83 \pm 7.21$ & $95.83 \pm 7.21$ \\
FI $\left(\mathrm{mg} \mathrm{fish}^{-1}\right)$ & $1.35 \pm 0.06$ & $1.40 \pm 0.14$ & $1.40 \pm 0.12$ & $1.16 \pm 0.18$ & $1.25 \pm 0.09$ \\
FCR & $2.56 \pm 0.03$ & $2.51 \pm 0.01$ & $2.51 \pm 0.02$ & $2.50 \pm 0.02$ & $2.53 \pm 0.02$ \\
PER & $0.79 \pm 0.05$ & $0.73 \pm 0.07$ & $0.75 \pm 0.08$ & $0.87 \pm 0.07$ & $0.83 \pm 0.06$ \\
HSI $(\%)$ & $1.47 \pm 0.03$ & $1.48 \pm 0.03$ & $1.47 \pm 0.01$ & $1.48 \pm 0.02$ & $1.49 \pm 0.03$ \\
\hline
\end{tabular}

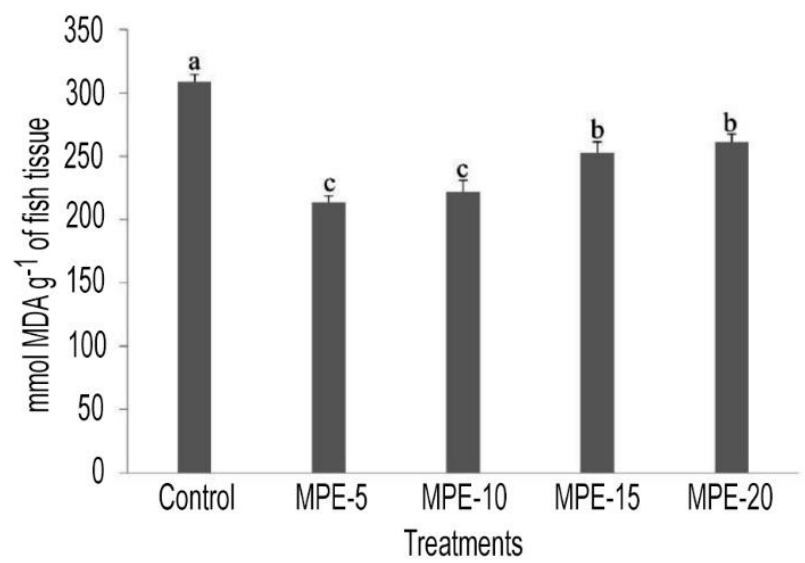

Figure 1. The concentration of malondialdehyde (MDA) as a measurement of lipid peroxidation in zebrafish (Danio rerio) muscle of control, MPE-5, MPE-10, MPE15 and MPE-20 groups, fed for eight weeks. Data are expressed as mean $\pm \mathrm{SD}(\mathrm{n}=3)$. Different letters indicate significant differences $(P<0.05)$ among experimental diets.

\section{Lipid peroxidation}

Lipid peroxidation is presented in Fig. 1. MDA levels were significantly lower $(P<0.05)$ in MPE-5 and MPE-10 groups, while the control group showed substantially higher MDA levels than PCs in all supplemented groups.

\section{Antioxidant enzymes activities}

Figure 2 suggests that the incorporation of MPE into zebrafish diets did not have a significant effect on GPX and SOD $(P>0.05)$ activities.

However, CAT activity significantly increased in MPE-10, MPE-15 and MPE-20 groups, as compared to the control and MPE-5 groups. No significant difference $(P<0.05)$ was found between the control and MPE-5 groups.

\section{DISCUSSION}

\section{Mango peel extract (MPE) phenolic compounds (PCs) profile}

Mango peel extract is a rich source of PCs such as phenolic acids and flavonoids, which exhibit high antio- 

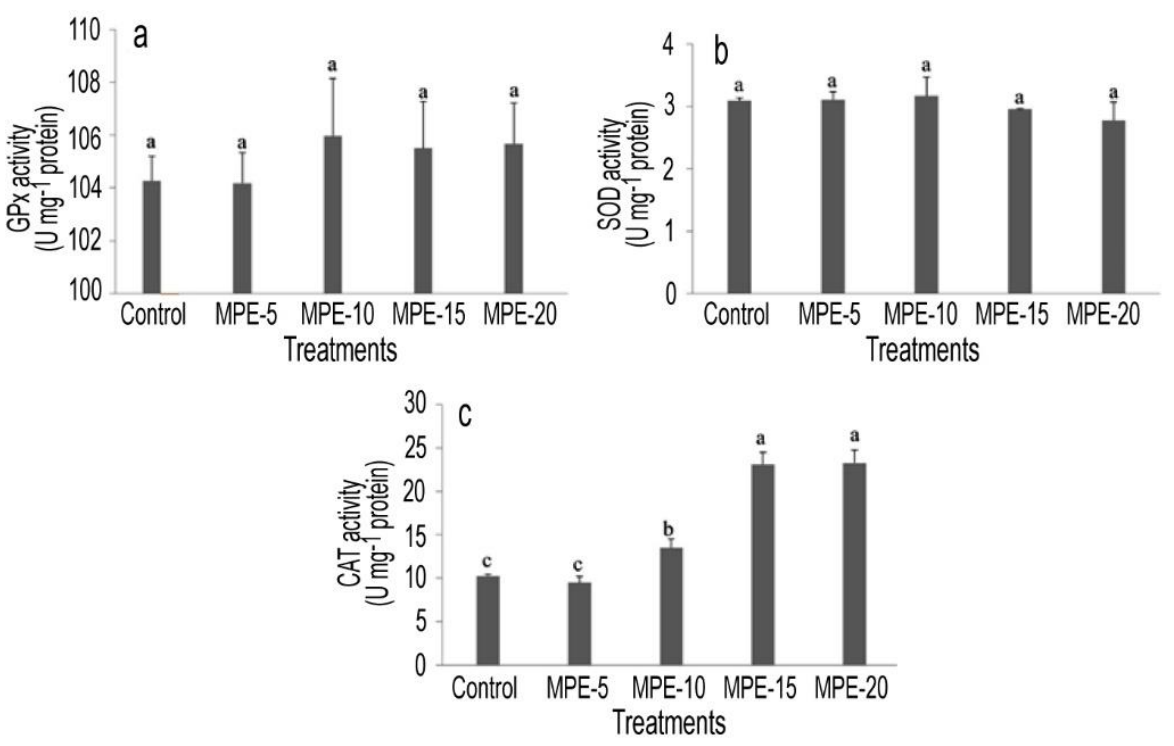

Figure 2. Antioxidant activities of a) GPX, b) SOD and c) CAT in zebrafish (Danio rerio) liver of control group, MPE-5, MPE-10, MPE-15 and MPE-20 groups, fed for eight weeks. Data are expressed as mean \pm SD $(n=3)$. Different letters indicate significant differences $(P<0.05)$ among experimental diets.

xidant activity both in vivo and in vitro. The PCs identified in this study have also been reported by Velderrain-Rodríguez et al. (2015) in which gallic acid, protocatechuic acid and 2-hydroxycinnamic acid were observed as major PCs in mango peel cv. Ataulfo extract. Additionally, Pacheco-Ordaz et al. (2018) indicated that mangiferin was the predominant PCs found in mango peel extract cv. Ataulfo. Other studies have reported the presence of methyl gallate, ethyl gallate, quercetin and isoquercetin in mango peel (Dorta et al., 2014), which is in agreement with our results.

\section{Growth performance and feed efficiency}

In aquaculture, the inclusion of some feed additives such as PCs from plant extracts could negatively affect growth performance and feed efficiency of fish (Buyukcapar et al., 2011). In the present study, the predominating compounds of the MPE PCs, which were incorporated into zebrafish (Danio rerio) feed, were phenolic acids (gallic, 2-hydroxycinnamic and protocatechuic acids; gallic acid derivatives such as methyl and ethyl gallate), flavonoids (quercetin and isoquercetin) and a polyphenol xanthone known as mangiferin, which did not show effects on growth performance and feed efficiency. Our results on growth performance and feed efficiency of zebrafish are in agreement with other studies conducted on gilthead sea bream (Sparus aurata) and rainbow trout (Oncorhynchus mykiss), where PCs extracted from olive oil (hydroxytyrosol and hydroxycinnamic acids) and purple maize (anthocyanins) were supplemented in the diets of these species (Sicuro et al., 2010; Villasante et al., 2015). The former may be attributed to the fact that the specific extracts used do not contain PCs of high molecular weight, such as condensed tannins (>5000 Da). Condensed tannins are considered as antinutrients for aquatic organisms since they can form stable complexes with proteins and can lead to reduced protein digestibility if they bind with digestive proteases, which is directly related to a reduction in growth performance and feed efficiency in farmed fish (Omnes et al., 2017). Therefore, the MPE-derived PCs used here are safe to administer to zebrafish in concentrations of up to $200 \mathrm{mg}$ per $\mathrm{kg}$ of feed.

\section{Lipid peroxidation}

Oxidative stress can promote the peroxidation of PUFAs in fish flesh. Lipid peroxidation is an important process that can lead to decreased quality of muscle, decreased shelf life, loss of nutritionally relevant compounds (e.g., PUFAs) and formation of off-flavors (Secci \& Parisi, 2016). Our results suggest that MPE PCs were absorbed, distributed and metabolized by zebrafish while acting as free radical scavengers and/or metal-chelating agents, indicated by a decrease in MDA production in zebrafish tissue. Lipid peroxidation depends on the amount of ROS produced, concentrations of $\mathrm{Fe}^{+2}$ and the level of endogenous and exogenous antioxidants (Ayala et al., 2014; Charão et al., 2014). The major PCs found in MPE, such as mangiferin, quercetin, gallic acid, and its derivatives, 
are characterized by high antioxidant capacity, which can mitigate oxidative stress through various mechanisms. For example, PCs can directly scavenge ROS through electron or hydrogen atom donation, or they can prevent their formation by chelating $\mathrm{Fe}^{+2}$ (and other transition metals) which promote oxidative stress by catalyzing hydroxyl radical formation via the Fenton reaction. There is evidence confirming that mangiferin, quercetin, gallic acids, and its derivatives have the ironchelating ability and can scavenge ROS which constitutes their main antioxidant mechanisms preventing lipid peroxidation in vitro (Boadi et al., 2003; Pardo-Andreu et al., 2008; Badhani et al., 2015). Previous experiments in our laboratory (LizárragaVelázquez et al., 2018b) suggest that MPE PCs delay MDA formation in fish oil, an effect also exhibited by the synthetic antioxidant BHT. Other in vitro studies report that the addition of grape PCs (catechin and procyanidins) and quince extracts (containing procyanidin B dimer and hydrocycinnamic acids) prevent lipid peroxidation in the muscle of different fish species during storage (Pazos et al., 2005; Fattouch et al., 2008). There are also studies that have demonstrated the effectiveness of PCs from plant extracts such as feed additives on preventing lipid peroxidation in animal tissue (Surai, 2014). However, there are only a limited number of studies on the use of PCs from plant extracts as a feed additive with antioxidant properties on the prevention of lipid peroxidation in the muscle of farmed fish. For example, Villasante et al. (2015) reported that dietary inclusion of an extract rich in anthocyanins increased $\omega 3$ (DHA, EPA, and all-cis-7,10,13,16,19-docosapentaenoic acid) and $\omega 6$ (cis, cis-9,12-octadecadienoic acid) total PUFA levels in the body and muscle of rainbow trout, respectively. Another study indicated that dietary administration of an olive oil extract rich in tyrosol and hydroxytyrosol decreased MDA levels in muscle of gilthead sea bream (Sicuro et al., 2010). The majority of the available reports on PCs in aquaculture have mainly focused on their use as immunostimulants (Nootash et al., 2013; Magrone et al., 2016). Our data suggest that MPE PCs significantly mitigate lipid peroxidation in zebrafish, which merits further investigation in fish that are used for human consumption to validate their use as feed supplements conclusively.

\section{Antioxidant enzymes activities}

During oxidative stress, tissues respond by inducing enzymatic and non-enzymatic antioxidant defense mechanisms. However, prolonged or enhanced oxidetive stress may depress the endogenous antioxidant system by decreasing enzyme activities of SOD, CAT and GPX (Samarghandian et al., 2016). These enzymes work jointly; SOD catalyzes' the dismutation of $\mathrm{O}_{2}{ }^{-2}$ to hydrogen peroxide $\left(\mathrm{H}_{2} \mathrm{O}_{2}\right)$, and molecular oxygen $\left(\mathrm{O}_{2}\right)$, which is then reduced to water and $\mathrm{O}_{2}$ by CAT and GPX. An inefficient endogenous antioxidant system can increase the production of $\mathrm{O}_{2}{ }^{-}$and $\mathrm{H}_{2} \mathrm{O}_{2}$ and can consequently produce highly reactive free radicals like $\mathrm{OH} \cdot$, which is considered the main initiator of lipid peroxidation (Ayala et al., 2014). PCs may offer cellular protection as indirect antioxidants by modulating the expression or activity of the predominating endogenous antioxidant enzymes (SOD, CAT and GPX). Sellamuthu et al. (2013) have reported that mangiferin can protect the kidney and liver of rats with induced oxidative stress, through an increase in SOD, CAT and GPX activities by activation of Nrf2 (nuclear factor-E2-related factor 2). Nrf2 is a transcription factor involved in the cellular antioxidant response, modulating gene expression of various enzymes and proteins. In the present study, MPE PCs did not have any effect on SOD and GPX activities in liver of zebrafish; we suggest that because oxidative stress was not induced, there was lower production of substrates $\left(\mathrm{O}_{2}{ }^{-}\right.$and $\left.\mathrm{H}_{2} \mathrm{O}_{2}\right)$ available to the antioxidant enzymes.

In contrast, CAT activity dose-dependently increased with MPE PCs. The increase in CAT activity suggests higher $\mathrm{H}_{2} \mathrm{O}_{2}$ concentrations in peroxisomes (Carvalho et al., 2012). $\mathrm{H}_{2} \mathrm{O}_{2}$ is the main cellular precursor of the hydroxyl radical which is considered as the most biologically active free radical, hence why the removal of $\mathrm{H}_{2} \mathrm{O}_{2}$ is a good strategy against oxidative stress (Karadag et al., 2014). Peroxisomal $\mathrm{H}_{2} \mathrm{O}_{2}$ is an important byproduct of the $\beta$-oxidation of fatty acids (Dansen \& Wirtz, 2001); therefore, the biological importance of CAT is evident in aquatic organisms because fatty acids are their main dietary lipids. According to our results, the intake of dietary MPE PCs at varying concentrations (100, 150 and $200 \mathrm{mg}$ PCs per $\mathrm{kg}$ of feed) enhances CAT activity, possibly due to high production of $\mathrm{H}_{2} \mathrm{O}_{2}$ in zebrafish liver.

\section{CONCLUSIONS}

Supplementation of MPE PCs did not impair growth performance and feed efficiency of zebrafish (Danio rerio). Supplementation of 50 and $100 \mathrm{mg}$ PCs per kg of feed decreased lipid peroxidation end-products (MDA) in zebrafish muscle and could, therefore, be used to avoid the decrease in EPA and DHA in fish flesh destined for human consumption, potentially providing health benefits to consumers. MPE PCs significantly increased hepatic CAT activity, without having a significant effect on SOD and GPX activities. Based on these findings, MPE PCs could be used as 
feed additives to preserve the nutritional quality of fish of commercial interest. Further studies are necessary to support these findings.

\section{ACKNOWLEDGMENTS}

Cynthia E. Lizárraga-Velázquez thanks CONACYT for a doctoral fellowship. We also, thanks to Alexis EmusMedina and Laura Aracely Contreras-Angulo for their technical support on the UPLC ESI-Q-TOF/MS/MS analysis, and the National Council for Science and Technology (SAGARPA-CONACYT grant 164673) for the financial support granted to C. Hernández.

\section{REFERENCES}

Ardiansyah, A. \& Indrayani, I. 2007. Natural antioxidants dietary and lipid oxidation analysis in zebrafish (Brachydanio rerio) tissue. HAYATI Journal of Biosciences, 14(3): 87-92. doi: 10.4308/hjb.14.3.87

Association of Official Analytical Chemists (AOAC). 2000. Official methods of analysis. Association of Official Analytical Chemists, Virginia.

Ayala, A., Muñoz, M.F. \& Argüelles, S. 2014. Lipid peroxidation: production, metabolism, and signaling mechanisms of malondialdehyde and 4-hydroxy-2nonenal. Oxidative Medicine and Cellular Longevity, 2014: 360438. doi: 10.1155/2014/360438.

Badhani, B., Sharma, N. \& Kakkar, R. 2015. Gallic acid: a versatile antioxidant with promising therapeutic and industrial applications. RSC Advances, 5(35): 2754027557. doi: 10.1039/C5RA01911G.

Boadi, W.Y., Iyere, P.A. \& Adunyah, S.E. 2003. Effect of quercetin and genistein on copper-and iron-induced lipid peroxidation in methyl linolenate. Journal of Applied Toxicology, 23(5): 363-369. doi: 10.1002/ jat.933.

Bradford, M.M. 1976. A rapid and sensitive method for the quantitation of microgram quantities of protein utilizing the principle of protein-dye binding. Analytical Biochemistry, 72(1-2): 248-254. doi: 10.1016/ 0003-2697(76)90527-3.

Buyukcapar, H., Atalay, A. \& Kamalak, A. 2011. Growth performance of Nile tilapia (Oreochromis niloticus) fed with diets containing different levels of hydrolyzable and condensed tannin. Journal of Agricultural Science and Technology, 13: 1045-1051.

Carvalho, S.C., Bernusso, V.A., Espíndola, E. \& Fernandes, M. 2012. Biomarker responses as an indication of contaminant effects in Oreochromis niloticus. Chemosphere, 89, 1: 60-69. doi: 10.1016/ j.chemosphere.2012.04.013.

Charão, M.F., Moro, A.M., Valentini, J., Brucker, N., Bubols, G.B., Bulcão, R.P., Baierle, M., Freitas, F.A.,
Nascimento, S.N., Barth, A., Linden, R., Saldiva P.H. \& Garcia, S.C. 2014. Exogenous and endogenous antioxidants attenuate the lipid peroxidation in workers occupationally exposed to paints. Drug and Chemical Toxicology, 37(1): 69-75. doi: 10.3109/014 80545.2013.806534.

Chulayo, A.Y. \& Muchenje V. 2015. A balanced perspective on animal welfare for improved meat and meat products. South African Journal of Animal Science, 45(5): 452-469. doi: 10.4314/sajas.v45i5.2

Dansen, T.B. \& Wirtz, K.W. 2001. Brand the peroxisome in oxidative stress. IUBMB Life, 51(4): 223-230. doi: 10.1080/152165401753311762.

Delgado-Lista, J., Perez-Martinez, P., Lopez-Miranda, J. \& Perez-Jimenez, F. 2012. Long chain omega-3 fatty acids and cardiovascular disease: a systematic review. British Journal of Nutrition 107(S2): S201-S213. doi: 10.1017/S0007114512001596.

Dorta, E., González, M., Lobo, M.G., Sánchez-Moreno, C. \& de Ancos, B. 2014. Screening of phenolic compounds in by-product extracts from mangoes (Mangifera indica L.) by HPLC-ESI-QTOF-MS and multivariate analysis for use as a food ingredient. Food Research International, 57: 51-60. doi: 10.1016/j. foodres.2014.01.012.

Ebeling, M.E. 1967. The Dumas method for nitrogen in feeds. Association of Official Analytical Chemists, 51: 766-770.

Fattouch, S., Sadok, S., Raboudi-Fattouch, F. \& Slama, M.B. 2008. Damage inhibition during refrigerated storage of mackerel (Scomber scombrus) fillets by a presoaking in quince (Cydonia oblonga) polyphenolic extract. International Journal of Food Science \& Technology, 43(11): 2056-2064. doi: 10.1111/j.13652621.2008.01823.x.

Karadag, H., Firat, Ö. \& Firat, Ö. 2014. Use of oxidative stress biomarkers in Cyprinus carpio L. for the evaluation of water pollution in Ataturk dam lake (Adiyaman, Turkey). Bulletin of Environmental Contamination and Toxicology, 92(3): 289-293. doi: 10.1007/s00128-013-1187-0.

Li, S., Tan, H.-Y., Wang, N., Zhang, Z.-J., Lao, L., Wong, C.-W. \& Feng, Y. 2015. The role of oxidative stress and antioxidants in liver diseases. International Journal of Molecular Sciences, 16(11): 26087-26124. doi: 10.3390/ijms161125942.

Lizárraga-Velázquez, C.E., Hernández, C., GonzálezAguilar, G.A. \& Basilio-Heredia, J. 2018a. Propiedades antioxidantes e inmunoestimulantes de polifenoles en peces carnívoros de cultivo. Ciencia UAT, 12(2): 127-136. doi: 10.29059/cienciauat. v12i2.904.

Lizárraga-Velázquez, C.E., Hernández, C., GonzálezAguilar, G.A. \& Heredia, J.B. 2018b. Effect of hydrophilic and lipophilic antioxidants from mango peel (Mangifera indica L. cv. Ataulfo) on lipid 
peroxidation in fish oil. CyTA - Journal of Food, 16(1): 1095-1101. doi: 10.1080/19476337.2018. 1513425 .

Magrone, T., Fontana, S., Laforgia, F., Dragone, T., Jirillo, E. \& Passantino, L. 2016. Administration of a polyphenol-enriched feed to farmed sea bass (Dicentrarchus labrax L.) modulates intestinal and spleen immune responses. Oxidative Medicine and Cellular Longevity, 2016(2): 1-11. doi: 10.1155/2016/ 2827567.

Martínez-Álvarez, R.M., Morales, A.E. \& Sanz, A. 2005. Antioxidant defenses in fish: biotic and abiotic factors. Reviews in Fish Biology and Fisheries, 15(1-2): 7588. doi: 10.1007/s11160-005-7846-4.

Nootash, S., Sheikhzadeh, N., Baradaran, B., Oushani, A.K., Maleki-Moghadam, M.R., Nofouzi, K., Monfaredan, A., Aghebati, L., Zare, F. \& Shabanzadeh, S. 2013. Green tea (Camellia sinensis) administration induces expression of immune-relevant genes and biochemical parameters in rainbow trout (Oncorhynchus mykiss). Fish and Shellfish Immunology, 35(6): 1916-1923. doi: 10.1016/j.fsi. 2013.09.030.

Omnes, M.-H., Le Goasduff, J., Le Delliou, H., Le Bayon, N., Quazuguel, P. \& Robin, J.H. 2017. Effects of dietary tannin on growth, feed utilization and digestibility, and carcass composition in juvenile European seabass (Dicentrarchus labrax L.). Aquaculture Reports, 6: 21-27. doi: 10.1016/j.aqrep. 2017.01.004.

Pacheco-Ordaz, R., Antunes-Ricardo, M., GutiérrezUribe, J.A. \& González-Aguilar, G.A. 2018. Intestinal permeability and cellular antioxidant activity of phenolic compounds from mango (Mangifera indica cv. Ataulfo) peels. International Journal of Molecular Sciences, 19(2): 514. doi: 10.3390/ijms19020514.

Pardo-Andreu, G.L., Barrios, M.F., Curti, C., Hernández, I., Merino, N., Lemus, Y., Martínez, I., Riano, A. \& Delgado, R. 2008. Protective effects of Mangifera indica L. extract (Vimang), and its major component mangiferin, on iron-induced oxidative damage to rat serum and liver. Pharmacological Research, 57(1): 7986. doi: 10.1016/j.phrs.2007.12.004.

Pazos, M., Gallardo, J.M., Torres, J.L. \& Medina, I. 2005. Activity of grape polyphenols as inhibitors of the oxidation of fish lipids and frozen fish muscle. Food Chemistry, 92(3): 547-557.

Poli, B.M. 2009. Farmed fish welfare-suffering assessment and impact on product quality. Italian Journal of Animal Science, 8(1): 139-160. doi: 10.4081/ijas.2009.s1.139.
Samarghandian, S., Farkhondeh, T., Samini, F. \& Borji, A. 2016. Protective effects of carvacrol against oxidative stress induced by chronic stress in rat's brain, liver, and kidney. Biochemistry Research International, 2016: 7 pp. doi: 10.1155/2016/2645237.

Secci, G. \& Parisi, G. 2016. From farm to fork: lipid oxidation in fish products. A review. Italian Journal of Animal Science, 15(1): 124-136. doi: 10.1080/18280 51X.2015.1128687.

Sekhon-Loodu, S., Warnakulasuriya, S.N., Rupasinghe, H.P.V. \& Shahidi, F. 2013. Antioxidant ability of fractionated apple peel phenolics to inhibit fish oil oxidation. Food Chemistry, 140(1-2): 189-196. doi: 10.1016/j.foodchem.2013.02.040.

Sellamuthu, P.S., Arulselvan, P., Kamalraj, S., Fakurazi, S. \& Kandasamy, M. 2013. Protective nature of mangiferin on oxidative stress and antioxidant status in tissues of streptozotocin-induced diabetic rats. ISRN Pharmacology, 2013: 750109. doi: 10.1155/ 2013/750109.

Shah, K.A., Patel, M.B., Patel, R.J. \& Parmar, P.K. 2010. Mangifera indica (Mango). Pharmacognosy Reviews, 4(7): 42-48. doi: 10.4103/0973-7847.65325.

Sicuro, B., Daprà, F., Gai, F., Palmegiano, G.B., Schiavone, R., Zilli, L. \& Vilella, S. 2010. Olive oil by-product as a natural antioxidant in gilthead sea bream (Sparus aurata) nutrition. Aquaculture International, 18(3): 511-522. doi: 10.1007/s10499009-9262-6.

Solé, M., Potrykus, J., Fernández-Díaz, C. \& Blasco, J. 2004. Variations on stress defences and metallothionein levels in the Senegal sole, Solea senegalensis, during early larval stages. Fish Physiology and Biochemistry, 30(1): 57-66. doi: 10.1007/s10695-0046786-6.

Surai, P.F. 2014. Polyphenol compounds in the chicken/animal diet: from the past to the future. Journal of Animal Physiology and Animal Nutrition, 98(1): 19-31. doi: 10.1111/jpn.12070.

Velderrain-Rodríguez, G.R., Ovando-Martínez, M., Villegas-Ochoa, M., Ayala-Zavala, J.F., WallMedrano, A., Álvarez-Parrilla, E. \& GonzálezAguilar, G.A. 2015. Antioxidant capacity and bioaccessibility of synergic mango (cv. Ataulfo) peel phenolic compounds in edible coatings applied to fresh-cut papaya. Food and Nutrition Sciences, 6: 365373. doi: 10.1590/1678-457X.6729.

Villasante, A., Patro, B., Chew, B., Becerra, M., Wacyk, J., Overturf, K., Powell, M.S. \& Hardy, R.W. 2015. Dietary intake of purple corn extract reduces fat body content and improves antioxidant capacity and n-3 po- 
lyunsaturated fatty acid profile in plasma of rainbow trout, Oncorhynchus mykiss. Journal of the World Aquaculture Society, 46(4): 381-394. doi: 10.1111/ jwas. 12206.

Received: 23 December 2018; Accepted: 18 March 2019 